\title{
SOME ADMIRALTY LAW ISSUES IN OFFSHORE OIL \& GAS DEVELOPMENT
}

\author{
W. WYLIE SPICER*
}

This paper examines the applicability of Admiralty law to offshore oil and gas activities. The discussion as to the maritime status of oil rigs includes an analysis of the nature of maritime claims, statutory limitation of liability and issues arising from conveyancing and mortgaging of "ships". Reference is made to relevant Canadian legislation and international treaties. The author concludes that some types of oil rigs should be regarded as "ships" and therefore subject to maritime law.

One might possibly take the position of the gentleman who dealt with the elephant by saying he could not define an elephant, but he knew what it was when he saw one, and it may be that that is the foundation of the learned Judge's judgment, that he cannot define "ship or vessel" but he knows this thing is not a ship or vessel.'

\section{INTRODUCTION}

An object that floats is not necessarily a "ship". ${ }^{2}$ However, much of Admiralty law is applicable only to those floating objects that can be classified as ships. Offshore drilling units are not what the draftsmen had in mind when statutory definitions of ships and vessels were fashioned. Indeed, offshore drilling units did not exist at the time. However, there were floating cranes, gas buoys, dumb barges and many other floating objects inhabiting the hinterlands of admiralty. Fortunately, they were involved in collisions, rendered and were subject to salvage services; they tried to limit their liability for losses caused by them and were even considerate enough to let their problems go to trial.

As a result of this history we are in a position to undertake a moderately considered view as to whether the latest in habitant of the fringes of admiralty can be classed a "ship". If an oil rig is a ship, there are many important consequences which follow such definition. This paper attempts to place oil rigs within the framework of Admiralty law.

The first part of the paper will review some of the cases on ships, concluding, with the possible exception of jack-ups, that offshore rigs are ships. A number of consequences will be discussed, including the nature of claims in rem, actions for damage caused by a ship (specifically collisions and blowouts), statutory limitation of liability, statutory civil liability for oil pollution under the Canada Shipping $\mathrm{Act}^{3}$ and the proposed amendments to The Oil and Gas Production and Conservation Act, ${ }^{4}$ conveyancing and mortgaging, and a number of miscellaneous matters concerning customs, immigration, and the coasting trade.

Oil rigs are a relatively new phenomenon in Admiralty law. There are very few questions to which there are certain, or any, answers. This paper embarks upon a first charting of the waters.

- McInnes, Cooper \& Robertson, Halifax, Nova Scotia.

1. Per Scrutton L.J. in Merchants Marine Insurance Co. Ltd v. North of England Protecting \& Indemnity Association (1926) 26 L1.L.R. 201 (C.A.) at 203.

2. See, for instance, Dr. Lushington in Raft of Timber (1844) $2 \mathrm{Wm}$. Rob. 251 at 255 "This is neither a ship or sea-going vessel; it is simply a raft of timber."

3. R.S.C. 1970, S-9 as am..

4. Contained in Bill C-48, An Act to regulate oil and gas interests in Canada lands and to amend the Oil and Gas Production and Conservation Act, 32nd Parliament, 1st Sess., $1980-81$. 


\section{ARE DRILLING UNITS “SHIPS”?}

The characterization of a drilling unit is a question of fact in every case. The Canada Shipping Act ${ }^{5}$ and the Federal Court Act ${ }^{6}$ contain definitions of ship ${ }^{7}$ substantially similar to the definition contained in the Merchant Shipping Act, 1894 (U.K.). The phrase "used in navigation" is the central element contained in all the definitions. The Federal Court Act definition is more expansive, and includes "used or designed for use in navigation" (emphasis added). A review of some cases dealing with these and similar definitions will provide some guidance as to whether a particular drilling unit can fairly be called a ship.

In Abbott's Law of Merchant Ships and Seamen ${ }^{9}$ the authors comment on the definition of ship in the Merchant Shipping Act as follows: ${ }^{10}$

The true criterion appears to be that the vessel ... is used for the transport of things or persons

from place to place, and it appears to be immaterial whether such a vessel goes to sea or not. She may be a ship although she is used entirely in inland waters. On the other hand, a vessel may have the form of a ship, and yet because she is not used in navigation, will not be entitled to be considered as a ship.

In The $M a c^{11}$ the English Court of Appeal considered the argument that a hopper-barge to which salvage services had been rendered was not a ship. The Court found that the barge was a ship even though she was not furnished with any means by which she could be propelled. She was towed from place to place and carried mud, and had a crew on board. Brett L.J. stated:12

... it seems plain to me that the word "ship" is not used in the technical sense as denoting a vessel of a particular rig. In popular language, ships are of different kinds; barques, brigs, schooners, sloops, cutters. The word includes anything floating in or upon the water built in a particular form and used for a particular purpose. In this case the vessel, if she may be so called, was built for a particular purpose, she was built as a hopper-barge; she has no motive-power, no means of progression within herself. Towing alone will not conduct her, she must have a rudder, and therefore she must have men on board to steer her. Barges are vessels in a certain sense; and as the word "ship" is not used in a strictly nautical meaning, but is used in a popular meaning, I think that this hopper-barge is a "ship" ... This hopper-barge is used for carrying men and mud; she is used in navigation; for to dredge up and carry away mud and gravel is an act done for the purposes of navigation.

In the Mayor of Southport v. Morriss ${ }^{13}$ the English Court of Queen's Bench considered whether or not a launch used for the purposes of carrying passengers on pleasure trips around an artificial lake half a mile long by 180 yards wide was a vessel "used in navigation". Lord Coleridge C. J. indicated at 361 that having regard to the size of the sheet of water the launch could not be said to be "used in navigation" and was not therefore a ship.

5. Supra n. 3.

6. R.S.C. 1970, (2nd Supp.), c. 10, as am..

7. S. 2 of the Canada Shipping Act, supra n. 3 reads as follows:

"Ship" includes:

(a) every description of vessel used in navigation and not propelled by oars, and

(b) for the purpose of Part $I$ and sections 647 to 652, every description of lighter, barge or like vessel used in navigation in Canada however propelled;

Section 2 of the Federal Court Act, id. provides:

"ship" includes any description of vessel or boat used or designed for use in navigation without regard to method or lack of propulsion.

8. 57 \& 58 Vict., c. 60 .

9. (14th ed. 1901).

10. Id at 2-3.

11. (1882) 7 P.D. 126.

12. Id at 130.

13. [1893] 1.Q.B. 359 . 
In Wells v. The Owners of The Gas Float Whitton No. $2^{14}$ the House of Lords concluded that a gas float is not a ship and could not be the subject of a claim for salvage within Admiralty jurisdiction. The Gas Float Whitton No. 2 was fifty feet long and twenty feet broad. Its hull was shaped something like a ship or boat, with its two ends similar to the bow of a vessel. It was made of iron and had no oars, mast, stern post, fore post nor rudder. No one was stationed on it and there was some evidence that it could not be used for navigation and was next to impossible to tow. The argument was made that because the gas float was exposed to the perils of the sea in the same way as a ship, it was sensible to regard it as being capable of being subjected to a Maritime lien for salvage. This argument was rejected by the House of Lords.

In the case of The Lighter No. $3^{15}$ the question was whether or not a dumb barge of 120 feet in length with a crew of two was required to exhibit certain navigational lights. An action had been brought by the owners of a steamship which had collided with the barge. Gorell Barnes J. was of the view that this barge was a ship.

In St. John Pilot Commissioners v. The Cumberland Railway and Coal Company ${ }^{16}$ the Privy Council, on appeal from the Supreme Court of Canada, considered whether vessels built to carry coal were ships. The vessels were described in the judgment by Lord Gorell:"17

... each of about $\mathbf{4 4 0}$ tons, and were described as "schooners" in the builders' statements and claims for drawback, and the certificates of registry in Nova Scotia certified that they had within themselves the power of independent navigation, though the facts shew that this statement cannot be treated as being sufficiently explicit. They were constructed with two short masts, which were fitted as derricks, with gaffs for discharging cargo, and carried small triangular sails and a jib. These sails were used to steady the vessels and assist them in strong breezes. The vessels could run before the wind, but could not be safely navigated as sailing vessels in the ordinary way, and were intended to be, and in fact were, towed from port to port. Each had a captain and crew, and was fitted with steering gear and anchors. If they had been fully rigged they would have been navigable by sails as ordinary schooners.

The Court concluded that these structures were ships and commented: ${ }^{18}$

There is nothing in the words of the section, when the definition of the word "ship" is considered, to indicate that at the time of moving in the pilotage waters a ship, to be under compulsion, must at the time possess independent practical power of moving herself. If that were so, it would seem to follow that any ordinary sailing vessel which was necessarily towed into port would not be within the section, and this can scarcely be the true meaning of the section.

In The Craighall ${ }^{9}$ the plaintiffs were the owners of a landing-stage situated on the Mersey River. They had brought an action against the defendant owners of a steamship to recover damages sustained in consequence of the steamship's collision with the landing-stage. The question for the Court of Appeal was whether preliminary acts ${ }^{20}$ should be filed. In order to answer this question it was necessary to consider whether the landing-stage was a vessel within the meaning of the Rules of the

14. [1897] A.C. 337.

15. (1902) 18 T.L.R. 322.

16. [1910] A.C. 209.

17. Id. at 213.

18. Id at 218.

19. [1910] P. 207.

20. In a collision case a preliminary act is filed by both parties. It is a document which sets out the navigational details of the accident, the weather, position, etc. It is not seen by the other side prior to each being filed. 
Supreme Court. Fletcher Moulton L. J. commented:21

To my mind it is clear beyond all question that this landing-stage is not a vessel. It is a huge floating structure intended to be a permanent structure and stationary, except in one respect, namely. that, for the convenience of passengers, it has the power of rising and falling with the water. Otherwise it is absolutely fixed. It has none of the characteristics of a vessel, ....

In The Mudlark ${ }^{22}$ the owners of a hopper barge sought to limit their liability pursuant to the provisions of the Merchant Shipping Act 1894 . The Court found that the hopper barge was a ship within the meaning of the 1894 legislation. The hopper barge was sea-going, had a rudder but had no means of propulsion and was ordinarily towed. The Court followed the case of The $\mathrm{Mac}^{23}$ and held that the hopper barge was a ship and that the owners were entitled to limitation of liability.

In The Upcerne ${ }^{24}$ the Court considered whether it had admiralty jurisdiction in a case involving damage to a floating gas buoy caused by a ship. The Court followed The Gas Float Whitton No. $2^{25}$ and made the following interesting comment: ${ }^{28}$

I therefore see no distinction in principle between an object of this kind, which, though floating, is affixed to the bottom of the sea in order that it may always be approximately in the same spot upon the surface of the water, and a pierhead, which is a more permanently fixed object.

In the case involving The Titan, ${ }^{27}$ on a motion for limitation of liability, the owners of the floating crane that had collided with a number of vessels were held entitled to limit their liability. The motion was unopposed.

In Polpen Shipping Company, Limited v. Commercial Union Assurance Company Limited ${ }^{23}$ the question was whether or not the plaintiff could recover against the defendant insurance company under a marine insurance policy in respect of a collision between their vessel and a British Government "flying boat". Mr. Justice Atkinson found that the sea plane was not a ship and commented: ${ }^{29}$

... it is impossible to hold that the words "ship or vessel" in this policy include this flying boat. I do not want to attempt a definition, but if I had to define "ship or vessel" I should say that it was any hollow structure intended to be used in navigation, i.e., intended to do its real work on the seas or other waters, and capable of free and ordered movement thereon from one place to another. A flying boat's real work is to fly. It is constructed for that purpose, and its ability to float and navigate short distances is merely incidental to that work. To my mind, that is where the difference lies.

In Cook v. Dredging \& Construction Company, Ltd..$^{30} \mathrm{Mr}$. Justice Jones of the Liverpool Assizes was called upon to decide whether the docks regulations applied with respect to an injury sustained by the plaintiff when he fell through an open hatch on board the defendant's barge. The structure had deck hatches, companion ladders and other equipment characteristic of a ship. It was, however, flat bottomed. It was similarly shaped at each end and had no rudder nor means of propulsion. At the

21. Supran. 19.

22. [1911] P.116.

23. Supra n. 11.

24. [1912] P. 160.

25. Supra n. 14.

26. Supre n. 24 at 166.

27. Swan, Hunter \& Wigham Richardson Ltd. ("The Titan") v. "Benwood"(1923) 14 L1.L.R. 484. See also Marine Craft Constructors Ltd. v. Erland Blomqvist (Engineers), Ltd. (1953) 1 L1.L.R. 514, where a pontoon was held to be a ship or vessel.

28. [1943] 1 K.B. 161.

29. Id at 167 .

30. (1958) 1 L1.L.R. 334. 
time of the accident it was being used in the process of dredging and land reclamation, not to bring anything up from the bed of the harbour. An engine on board forced sludge from the place where the barge was moored at shore to where it was discharged and used for the purpose of reclamation of land. The structure had been moored in one location for eighteen months prior to the date of the plaintiff's action, but from time to time it was moved by tow to any place where it was required. Mr. Justice Jones found that it was a ship: "I think that it should be held that it was used in navigation, as it had been moved often on the sea from place to place as occasion required ...."31

From the English authorities ${ }^{32}$ one may conclude that ship status is appropriate for at least all forms of submersible or semi-submersible offshore drilling units. The Canadian cases, however, do not really enable one to form any opinion with much certainty.

In $R$. v. The "Gulf Aladdin" ${ }^{33}$ it was necessary to decide whether a barge was a ship in order to ground a prosecution for oil pollution pursuant to provisions of the Canada Shipping Act. The barge Gulf Aladdin was a tanker barge designed to carry and discharge oil, carrying no crew and having no accommodations for a crew. It had no means of propulsion and had no rudder or navigational equipment on board. Its means of getting from place to place was by tow. Relying on a decision of Judson J. in the City of Fort William v. McNamara Construction Co. Ltd ${ }^{34}$ the Court concluded: “... unless the vessel under consideration can navigate, whether independently or when under tow, then it is not a ship." ${ }^{25}$ In the result the oil pollution prosecution was dismissed. No mention was made of the decision of the Exchequer Court in Falconbridge NickelMines Ltd. v. Chimo Shipping $L t d,{ }^{36}$ in which Mr. Justice Kerr decided, using the Canada Shipping Act definition, that a barge used for lightering of cargo was a ship.

One of the most peculiar decisions and one which is most directly on point is Dome Petroleum Limited v. N. Bunker Hunt, ${ }^{37}$ a decision of Mr. Justice Dubé, Federal Court Trial Division. The defendants had raised the question of the Federal Court's jurisdiction over a contract between the parties for drilling oil in the Beaufort Sea. This operation involved the use of drilling ships. Mr. Justice Dube found that the Court did not have admiralty jurisdiction because the agreement was, in substance, an agreement for the drilling of a well and had nothing to do with Admiralty. Referring to the definition of ship in the Canada Shipping Act, he concluded that the drilling ships were not navigating at the time that they were carrying out their main function, which was drilling through land, and therefore were not ships. He found that any navigation necessary to put the vessel into position was merely incidental.

This is an odd decision in a number of respects. There was no reason for

31. Id. at 338.

32. See also, Weeks v.Ross [1913] 2 K.B.229; The Blow Boat [1912] P. 217; Chandler v. Blogg [1898] 1 Q.B. 32.

33. (1975) 27 C.C.C. (2d) 562 (B.C. Co. Ct.).

34. (1957) 10 D.L.R. (2d) 625 (Ont. C.A.).

35. Supra n. 33 at 567.

36. [1969] 2 Ex. C.R. 261.

37. [1978] 1 F.C. 11. 
the Court to advert to the definition of ship in the Canada Shipping Act at all. The relevant definition for the purposes of Federal Court jurisdiction would have been the definition in the Federal Court Act which includes the more expansive phrase "used or designed for use in navigation". The definition in the Canada Shipping Act should have been sufficient in any event for Mr. Justice Dubé to reach his conclusion, but certainly the proper definition for reference would have been the one contained in the Federal Court Act. The judgment also implies that one must look at what the structure is doing at the precise moment giving rise to the cause of action. If it were stationary at that point in time it would seem that $\mathrm{Mr}$. Justice Dubé would find it was not a ship. However, if it were being towed into position perhaps then it would be a ship. There is some authority for the proposition that a structure can be a vessel at one point in time but not at another. However, this change of character would seem to be based on a substantial change in the functioning of the unit as a whole, e.g. being transformed from a ship to coal hulk. It is clear from the English authorities that what is required is a real transformation of the nature of the structure itsel $f^{38}$ not merely the same structure carrying out a different function. There is Canadian authority relying on the Federal Court definition, for the proposition that if something is designed for use as a vessel then it will be treated thereafter as a vessel unless it has been

38. The European and Austrialian Royal Mail Company (Limited) v. The Peninsular and Oriental Steam Navigation Company (1866) 14 L.T. 704. 
taken apart in such a way that it no longer resembles in any fashion a ship..$^{39}$

Oil rigs are "used in navigation," with drillships and self-propelled semi-submersibles being capable of independent navigation. All rigs work on the ocean transporting individuals and drilling equipment from place to place. They are subject to, and are potential sources of, marine casualties. The fact that they are more or less stationary for periods of time should not deprive the unit of ship status. Since a barge without power can be called a ship, even a jack-up rig may be given ship status. There should be no doubt that drillships and semi-submersibles, whether self-propelled or not, are ships.

This conclusion is not only consistent with the cases, it also reflects the modern reality. Shipping legislation is intended to accomplish at least two purposes: to give benefits to shipowners and others interested in ships whether as crew, shippers, or mortgagees; and to place responsibilities on shipowners for the benefit of all those that use the seas. An oil rig, her owners, and those interested in her should be governed by the same statutory scheme. The fact is that rigs are registered as ships, mortgaged by marine mortgages, classed by maritime classification societies, ${ }^{10}$ insured for hull and machinery on marine forms and, frequently carry third party protection and indemnity insurance through traditional entries in $P$

39. The Hamilton Harbour Commissioners v. The "A.M. German "[1973] F.C. 1254. In this case three ships tied up at a dock and about to be scrapped were "ships". The Trial judge commented at 1260 :

... having once qualified as a "ship" because it was designed for such use, the property never loses its classification ... regardless of changes to it unless it be taken apart to the extent that the separated components would merely be individual objects which were used in the construction of the ship.

Since the date of presentation of this paper, the Federal Court of Appeal, rendered judgment in The Queen v. Saint John Shipbuilding and Dry Dock Co. L td et al unreported, 7 July 1981, A-638-79 (Fed. C.A.). Urie J., speaking for the Court of Appeal, considered whether a barge fitted with a heavy crane and described as a floating crane, not capable of self-propulsion, was a ship within the meaning of The Federal Court Act definition. It was argued that it was not a ship but rather a crane on a floating platform. The Court reviewed a number of decisions, unfortunately not including Dome Petroleum or The "Gulf Aladdin", and concluded (at p. 13 of the judgment):

... The definition of ship in the Federal Court Act is not exclusive but inclusive. It, thus, enlarges the term. She was a barge built for use on water. She was capable of being moved from place to place and was so moved from time to time, as it was in this case to unload the cargo. ... She was capable of carrying cargo and had, in fact, done so. She was certainly capable of carrying people and obviously had to do so to enable the crew to carry out their duties. While it appears that she was not capable of navigation herself and was not self-propelled, those facts do not detract from the fact that she was built to do something on water, requiring movement from place to place. The Court concluded that the structure was a ship. Strangely, the Court seemed to have been advised that the definition of ship in the Federal Court Act had changed from that referred to in n. 7 supra. For some reason the Court seemed to be of the view that the definition of "ship" in the Maritime Code Act S.C. 1977-78, c. 41 was in effect. This is simply wrong; the provisions of this legislation have not yet been proclaimed. It does not seem however that the Court's mistake in this regard would substantially alter their opinion as to whether or not the floating crane was a ship. Having regard to the words of Urie J. there can be little doubt that the law in Canada is finally moving to a position where one can say that a semi-submersible rig is a ship. It is only unfortunate that the Court did not take the opportunity to comment on the Dome Petroleum and "Gulf Aladdin" cases, both of which are clearly in conflict with this most recent decision. Indeed the very broad description at the end of the quote above provides some argument that a jack-up is a ship. After all a jack-up is built to carry driling equipment on water, and must move from place to place.

40. Havin, "Production Systems as viewed by Certification Society",Proceedings of the $9 t h$ Environmental Workshop, Arctic Institute of North America (1980), 121 at 124. 
\& I Clubs with the usual rules or special rules adopted for rigs. ${ }^{41}$ Rigs are chartered and carry marine crews, are treated by representatives of the Department of Transport responsible for ship safety ("Ship Safety") either as steamships, ships or barges and are expected to comply with the relevant regulations. Foreign owned rigs in Canadian waters must comply in part with the Non-Canadian Ship Safety Order..$^{42}$

The position of Ship Safety appears to be that a rig may be considered to be a ship when she is actually in motion, but not when attached to the ground by anchors at a drilling site. However, it is inconsistent with authority to suggest this on again, off again status for rigs. It would be most unlikely, in the face of the bulk of the case law, that a court would adopt this position. Nor should it, as this would produce a situation of great uncertainty. Is a dynamically positioned rig any more or less a ship than a semi-submersible with eight anchors down?

Thus, the Gulf Aladdin ${ }^{43}$ and Dome Petroleum ${ }^{41}$ cases seem inconsistent with most of the authority. The mistake in Gulf Aladdin was basing the decision on a lack of appropriate external indicia of a ship when quite obviously the function of the barge was to transport cargo. It is submitted the error in Dome Petroleum results from the judge's failure to consider anything other than the fact that the main function of a drill ship is to drill holes in the ground. To extend that analysis one would be forced to conclude that only vessels whose main function was the bare transportation of individuals or goods can be ships. This would exclude many special purpose "ships".

It seems clear that rigs are ships. However, if there are sceptics remaining, the final trump card is that the statutory definitions of ship commence with "ship includes" (emphasis added). The definition is therefore not exhaustive and, in the words of the Supreme Court of Canada can "be applied to some things to which it would not ordinarily be applicable". ${ }^{45}$ United States authority ${ }^{46}$ accords with the view that at least floating rigs

41. See M. Summerskill, Oil Rigs: Law and Insurance (1980).

42. C.R.C. 1978, c. 1452. The jack-up off Sable Island has been inspected by Canadian Ship Safety for this purpose.

43. Supra n. 33.

44. Supra n. 37.

45. Ricard v. Lord [1941] S.C.R. 1; see also R. v. Beru [1936] 4 D.L.R.; Wardle v. Man Farm Loans Association (1953) 9 W.W.R. (N.S.) 529, varied on other grounds [1956] S.C.R. 3.

46. In Offshore Company and the Fidelity and Casualty Company of New York v. Robison 1959 A.M.C. 2049 the question was whether a roustabout on a drilling platform was a seaman for Jones Act purposes. The court reviewed a number of cases on the maritime status of a mobile drilling platform, in this case one with retractable legs, and concluded that a vessel may include a special purpose structure not usually employed as a means of transport by water but designed to float on water. In Producers Drilling Company et al v. Gray 1966 A.M.C. 1260 the 5 th Circuit concluded that a submersible drilling barge was a vessel. In this case the barge rested on the bottom while drilling. A fixed of fshore platform, however, was considered not to be a vessel in Laffland Brothers Company v. Roberts A.M.C. 1463. In A-1 Industries Inc. v. Barge Rig $\$ 2$ et al 1979 A.M.C. 1486 the District Court for the Eastern District of Louisiana concluded that an oil drilling barge capable of use as a means of transportation over water was a ship. A floating dry-dock is not, however, a vessel. Cope v. Vallette Dry Dock Co. 119 U.S. 625 (U.S.S.C.) Gilmore and Black. The Law of Admiralty (2nd ed. 1975) are of the view that the term vessel "is applied to floating structures capable of transporting something over the water". 
are ships. ${ }^{47}$

\section{THE STATUS OF MARITIME CLAIMS - IN REM CLAIMS AND THE FEDERAL COURT}

Not all the types of claims in rem (an action against the thing itself) enforceable against a ship will be discussed. One such claim which may be enforceable against a rig (assuming it is a ship) is an action in rem for damage caused by a ship. In order to paint the picture, a brief summary of the nature and effect of in rem claims is necessary.

Ships ${ }^{48}$ may be made the subject of an action in rem in the Federal Court of Canada in the circumstances referred to in ss. 22(2) and 43 of the Federal Court Act. ${ }^{49}$ The action can be defended by showing that there is no in rem liability in the particular case.

Actions in rem are usually accompanied by the arrest of the ship. ${ }^{50}$ This is done without any hearing in advance. ${ }^{51} \mathrm{~A}$ statement of claim is filed along with an affidavit to lead warrant, whereupon the Federal Court office will issue a warrant to arrest the ship.

The warrant of arrest must be served on the vessel within the territorial jurisdiction of the Court. ${ }^{52}$ Section 55 of the Federal Court Act provides that the process of the Court:

... shall run throughout Canada, including its territorial waters, and any other place to which legislation enacted by the Parliament of Canada has been made applicable.

Rigs situated within the 200 mile zone are subject to arrest by virtue of this provision..$^{53}$ Indeed, a rig operating in any location that is subject to federal or provincial licenses or leases to explore for, drill for or take any petroleum, natural gas or minerals ${ }^{54}$ would be subject to arrest.

47. For additional reading see: Summerskill, supra n. 41; R. Temperley, Merchant Shipping Acts (7th ed. 1976) 274-278; D. Thomas, Maritime Liens (1980); P. Swan, Ocean Oil and Gas Drilling \& The Law (1979); W. Spicer, "Questions of Definition and Jurisdiction respecting Offshore Oil Rigs", in Gold (ed.), New Directions in Maritime Law 1978 (1978) 70.

48. And in some circumstances cargo, freight and proceeds of a court ordered sale.

49. Supra n. 6. These sections are reproduced in Appendix A, infra

50. Federal Court Rule 1003.

51. The arrest procedure in the United States has recently come under attack with varying degrees of success, on the ground that it violates due process. See, for instance, Grand Bahama Petroleum Co. Ltd. v. Canadian Transportation A gencies Ltd. 1978 A.M.C. 789 (W.D. Wash); Karl Senner Inc. v. The M/V Acadian Valour 1980 A.M.C. 1 (La.). This argument would fail in Canada where due process in the Canadian Bill of Rights has not been given overriding effect in relation to other federal enactments. See Curr v. the Queen (1972) 26 D.L.R. (3d) 603 (S.C.C.).

52. As must the statement of claim in an in rem proceeding. See Castrique v. Imrie 4 L.R.H.L. 414. There is no provision for substituted service of the statement of claim or warrant of arrest. This is because service constitutes constructive notice of a claim to all persons who might be interested in the ship. See The Prins Bernhard [1964] P. 117 at 131-2; The Mary 9 Cranch 126 (U.S. 1815). Failure.to follow important rules related to jurisdiction may, if the ship is sold in the proceeding. jeopardize the recognition of the sale by a Foreign Court. See Spicer, "Court Ordered Sale of Vessels" (1980) 11 J.M.L.A.C. 239.

53. Inter alia, by s. 4(2) of the Territorial Sea and Fishing Zones Act, R.S.C. 1970 c. T-7:

Unless otherwise specified therein, the laws of Canada respecting fishing and the exploitation of the living resources of the sea apply to the fishing zones of Canada in the same way and to the same extent as they apply to the territorial sea of Canada.

54. From the definition of "In Canada" contained in s. 255 of An Act to amend the Income Tax Act S.C. 1970-71-72, c. 63 as am., which extends the geographic limits of Canada tax law. See s. 3 of amendment to the Oil and Gas Production and Conservation Act which extends legislative jurisdiction to the edge of the continental margin. 
Once arrested, the rig would not be permitted to move unless all parties consent, the Court so orders it, ${ }^{55}$ or, as is usually the case, adequate security ${ }^{56}$ is provided for the plaintiff's claim. In the latter circumstance the rig would then be released. The security stands in the place of the ship; ${ }^{57}$ accordingly the amount will not exceed the value of the ship, ${ }^{58}$ but this is without prejudice to liability in excess of the security.

Admiralty claims cognizable in the Federal Court in an action in rem will either be secured by a maritime lien $^{59}$ or will merely give rise to a right to proceed in rem. ${ }^{60}$ In order for an in rem claim not secured by a maritime lien to succeed there must be some in personam liability established against the owner..$^{81}$ A claim secured by a maritime lien does not depend for success on establishing any in personam liability of the registered owner and may be enforced against a ship for claims arising when the ship was on charter, including, a demise or bareboat charter. As will be dealt with infra ${ }^{63}$ maritime liens (except masters' disbursements) $)^{84}$ and some claims giving rise to a right to proceed in rem survive a change in ownership of the ship ${ }^{65}$ (other than a change effected by sale in an in rem proceeding).

The Federal Court will, quite apart from its jurisdiction in rem, grant Mareva injunctions in appropriate circumstances ${ }^{66}$ to restrain removal of assets (including ships) from the jurisdiction of the Court.

The designation of an oil rig as a ship carries with it a number of important consequences. With this brief and general background on the nature of admiralty in rem claims, the admiralty cause of action of damage by a ship, whether by collision or otherwise, and the important admiralty par-

55. Federal Court rule 1003(a). Arrest does not affect possession.

56. The plaintiff is entitled to security in an amount which will cover the claim plus interest and costs based on his best arguable case. The "Moschanthy" [1971] 1 Lloyds Rep 37; Hassan Ismail et al v. The Golden Med, unreported, 14 A ugust 1980, T-3772-80(Fed.Ct.).

57. Beaudette v. S.S. "Ethel Q" (1916) 16 Ex. C.R. 280.

58. The Charlotte [1920] P. 78.

59. Traditionally, claims of salvage, crew wages, master wages and disbursements, collision, respondentia and bottomry. In Canada, pilotage dues for services rendered are also secured by a maritime lien. Osborn Refrigeration Sales \& Service Inc. v. The Atlantean 1 [1979] 2 F.C. 661 at 676.

60. Claims other than those referred to in $\mathbf{n . 5 9}$ are enumerated in s. 22(2) of the Federal Court Act.

61. Westcan Stevedoring Ltd. v. The Ship Armar [1973] F.C. 1232; Coastal Equipment Agencies Ltd. v. The Ship "Comer" [1970] Ex. C.R. 12. Arguments of agency are a vailable to establish liability on the owner. The Great Eastern (1865-1869) 2 L.R.A.\& E. 87.

62. Goodwin Johnson Ltd. v. Scow AT \& B No. 28 [1954] 4 D.L.R. 1 (S.C.C.). It is sufficient that the owner voluntarily put the ship into the control of another. There are cases where in rem liability has been established where the ship was under the control of a thief. Phillips v. The Highland Railway Co. (1883) 8 App. Cas. 329.

63. See section IV, Conveyancing and Mortgaging.

64. See s. 43(3) of the Federal Court Act, supra n. 6.

65. With respect to maritime lien claims this is consistent with the view that in personam liability is unnecessary. However claims not secured by maritime liens which by virtue of s. 43(3) of the Federal Court Act survive a change in beneficial ownership are problematic since it is difficult to see how a plaintiff who commences action subsequent to the change in ownership can establish in personam liability on the new owners.

66. E.g. Elesquro Inc. v. Ssargyong Shipping Co. Ltd. (1980) 117 D.L.R. (3d) 105. See generally, Ibrahim Shanker v. Distos Compania Naviera S.A. "The Siskina" [1978] 1 Lloyd's Rep. 1 (H.L.). 
tial defence of statutory limitation of liability will now be considered in more detail.

\section{A. Damage By a Ship}

The largest single cause of mobile rig accidents in the last twenty-five years has been blowouts. ${ }^{67}$ Of 140 accidents 31 have been attributable to blowouts. ${ }^{68}$ Climatic conditions are hazardous, and the Grand Banks area off the east coast of Canada is one of the largest fog generators in the world ${ }^{69}$ Due to this treacherous climate off the east coast, and to the presence of deep water, pack ice and ice bergs, self-propelled semisubmersible units are the most suitable drilling units for both the exploration and production phases of East Coast offshore development. There can be little doubt that these units are ships.

Can the type of loss caused by blowouts arising out of the use of a ship, give rise to a maritime lien for damage caused by a ship, ${ }^{70}$ enforceable against the res regardless of the lack of in personam liability on the part of the owner?

In Outhouse v. The Thorshavn ${ }^{71}$ a claim in rem was made against the defendant ship by the owners of a number of crated live lobsters lying in the waters of the Strait of Canso. The defendant ship had run aground and, in order to lighten her, a quantity of her cargo of oil was pumped into the waters of the Strait, which allegedly caused damage to the lobsters, crates and connecting lines. The Court decided that this type of claim could be construed as damage by a ship: ${ }^{72}$

... damage by a ship means damage done by those in charge of a ship, with the ship as the noxious instrument... we do not mean necessarily a damage caused by the whole body. We include damage by a part of that body ... damages caused by ... her pumps are damages by the ship.

Certainly on the basis of this case one can argue that a blowout caused by a failure on board the rig, would be damage by a ship, notwithstanding that the oil actually causing the damage came from underground. There is no indication in the case that any importance was attributed to the fact that it was the ship's cargo which fouled the plaintiffs' property.

In order for an action in rem to be sustained in these circumstances there must exist a conjunction between the wrongful act or neglect and the instrumentality of the ship or part of it as the noxious agent. ${ }^{73}$ At first blush the governing principles reflected in the case law would tend to the conclusion that a blowout is at best (or worst) borderline "damage by a ship":"4

For a maritime lien for damage to arise it is not sufficient to show that those in charge and control of

the ship are in breach of duty; it must be further shown that the ship herself was the active means by which the damage was inflicted.

In Currie v. M'Knight Lord Watson commented that the damage lien "must be either the direct result or the natural consequence of a wrongful

67. L. Leblanc, "Tracing the Course of Rig Mishaps" (March 1981) Offshore 51.

68. Id.

69. S. Romanski, "Oil and Gas Development Concepts, Sable Island and Hibernia" in Proceedings, Offshore Environment in the 80 's (1980).

70. Supra n. 6 s. 22(2)(d).

71. [1935] Ex. C.R. 120.

72. Id at 122.

73. The Vera Cruz (No. 2) (1884) 9 P.C. 96; Currie v. M'Knight [1897] A.C. 97.

74. Thomas, supra n. 47 at 131. 
act or manoeuver of the ship...." ${ }^{75}$ In that case, there was no "damage by a ship" when the crew of one vessel let go the lines of another, causing the latter damage.

In a recent decision of the House of Lords, Lord Diplock commented on the meaning of "damage caused by a ship": ${ }^{76}$

To fall within the phrase not only must the damage be the direct result or natural consequence of something done by those engaged in the navigation of the ship but the ship itself must be the actual instrument by which the damage was done ... physical contact between the ship and whatever object sustains the damage is not essential - a ship may negligently cause a wash by which some other vessel or some property on shore is damaged.

A wrongful act causing damage by those in charge of the navigation of the ship is the traditional essence of the claim. Is this open to expansion in the light of modern conditions? It is submitted that the answer is yes. Oil rigs are a fact of maritime commerce, and utilize the sea in increasing numbers. The actionable act does not, even according to the older cases, have to be an error in navigation but merely one by those responsible for navigation. Thus, it seems a very short step to say that in the case of a rig where the possibility of causing loss to third parties may be in the hands of someone other than the marine crew, it is consistent with the conceptual rationale for the lien to extend it to cover some types of blowouts caused by a rig. The rationale for the lien is twofold - to encourage safe and prudent use of the seas and to secure a remedy for those injuriously affected by the negligence of others. ${ }^{77}$

There may be, of course, problems for a potential plaintiff. If the blowout arises during drilling it may be difficult to argue, in the case of a subsurface completion, that the "ship" is in any sense the noxious instrument even if control is exercised from the rig itself. Similar problems may arise from a blowout during a workover on the ocean floor.

A defendant owner may want to argue that if there is negligence, the damage was caused totally without actual fault or privity on the part of the owners but was caused by either:

a. an act or omission in the management or navigation of the ship by persons whether on board or not; or

b. any other act or omission of any person on board the ship.

This argument would be made in an attempt to limit liability, and is discussed in detail infra.

A situation which will certainly produce an identifiable plaintiff very quickly is a collision. One may occur between the rig and supply boats with whom there may exist relevant contractual relationships. One may also occur with an unrelated vessel, either while the rig is stationary over a drilling hole or is moving, perhaps unassisted, to a new drilling location. Collisions can happen when the rig is in harbour for repairs, if for example the rig's moorings were broken in a storm and it damaged objects on shore.

All of these situations, assuming fault on the part of the rig operator, will give rise to an action in rem against the rig.

What are some of the indicia which may assist a plaintiff in establishing fault against the rig? If the incident occurred while the rig was underway

75. Supra n. 73 at 106.

76. The "Eschersheim" [1976] 2 Lloyd's Rep. 1 at 8.

77. Thomas, supra n. 47 at 124. 
it might be suggested that there had been failure to comply with generally accepted rules of good seamanship.$^{78}$ This might lead to a finding of negligence. The Collision Regulations ${ }^{79}$ would arguably also be applicable, the definition of vessel being: ${ }^{80}$

every description of water craft, including non-displacement craft and seaplanes, used or capable of being used as a means of transportation on water.

These regulations are the rules of the road at sea intended to prevent collisions, provide for required lights, sound signals, etc.. At the very least a rig would be a vessel "restricted in ability to manoeuvre" pected to act accordingly.

Other regulations which may be relevant are the Ships' Deck Watch Regulations, ${ }^{82}$ which apply to all self-propelled ships of more than five tons and would apply off Newfoundland; and the Safe Manning Regulations, ${ }^{83}$ which apply to Canadian registered steamships of more than five tons wherever located. The latter regulations have equivalents in the shipping legislation of many countries. If the vessel is a steamship (which, it is suggested, would include a self-propelled rig) registered or owned in Canada, the Canada Shipping Act ${ }^{84}$ requires that engineers with certain qualifications be maintained on board for all voyages. The point is that ships must comply with a labyrinth of shipping regulations and any failure to comply resulting in a loss will almost certainly assist a plaintiff's claim.

The difficulty is that none of these regulations were drafted with oil rigs in mind, yet rigs appear to have been swept up under them because of their ship status. Indeed, representatives of the Department of Transport, responsible for safety and manning, treat rigs variously as steamships, ships or barges, apparently depending on their capability for self-propulsion. There is a serious need of rationalization and legislative amendment to deal specifically with navigational and safety issues on rigs, both when moored and when in motion.

B. Statutory Limitation of Liability ${ }^{85}$

One of the most significant benefits accorded to shipowners and operators is the right to limit liability to persons who have suffered loss or damage as a result of, inter alia, negligent navigation or management of the ship or other acts or omissions of persons on board the ship, ${ }^{86}$ where it can be established that the loss occurred without "actual fault or privity" ${ }^{87}$ on the part of the owner or operator. If successfully argued, this

78. McGuffie, The Law of Collisions at Sea (1961) 4.

79. C.R.C. 1978 , c. 1416.

80. Id. Schedule 1, Rule 3(a).

81. Id. Rule 3(g) defines this to include, inter alia "a vessel engaged in dredging, surveying or underwater operations".

82. C.R.C. 1978 , c. 1481 .

83. C.R.C. 1978, c. 1466.

84. Supra n. 3, s. 110.

85. Id. Part XIV. Limitation developed to protect ship owners from losses in situations where they could not exercise any real control over their masters and crews. See Vancouver v. Rhodes, (1955] 1 D.L.R. 139; Dr. Lushington in The Amalia 1 Moo P.C. (N.S.) 471 at 473: "The principle of limited liability is, that full indemnity, the natural right of justice, shall be abridged for political reasons."

86. Jd. s. 647(2).

87. Id. 
limitation would restrict recovery in a collision case for which the rig was totally at fault and in which there were no personal injury claims as follows: ${ }^{88}$

Damage to innocent ship

Limitation tonnage of rig

Limitation fund - Amount

recoverable (approx.)
$\$ 2$ Million

10,000

$10,000 \times \$ 100=\$ 1$ Million

The Limitation Fund is available to answer all claims. ${ }^{89} \mathrm{It}$ is calculated on the basis of tonnage and does not fluctuate if, for example, the rig were only fifty per cent to blame. It is a limit of liability.

"Actual fault or privity" is a much litigated phrase. ${ }^{90}$ The onus is on the owner or operator to demonstrate that the loss occurred without actual fault or privity on his part. In the case of a corporation with a marine department, an omission on the part of the manager of that department (even if not an officer or director) may constitute actual fault or privity depriving the company of the right to limit ${ }^{91}$ if the fault is in $a n y^{92}$ way causative.

Problems may arise in limitation proceedings in defining the physical extent of the "ship" when dealing with a rig. Even assuming a causative error in management to which the owner was not privy, can it be said, for example, that improper placement of a Blowout Preventer not on the ship is an error in management of the ship? Could it not be said that (a) it was an error in management of the drilling operation; or (b) it was an error with respect to a Blowout Preventer which is not part of the ship? This is a difficult question. Does it matter, for purposes of limitation, whether an improper adjustment not constituting management but being an act or omission, is made by a person actually on the platform, or by a diver on the ocean floor? This is probably an easier situation, since in the case of the diver there was no right to limit because he was not "on board" the ship.

The test for assessing actual fault is objective. Persons who take on the responsibility of shipowning or operating ships (perhaps as part of an otherwise non-marine business) will be judged according to the standards of those whose main business is shipping: ${ }^{: 4}$

... any company which embarks on the business of shipowning must accept the obligation to en. sure efficient management of its ships if it is to enjoy the very considerable benefits conferred by the statutory right to limitation.

88. The limitation tonnage of the vessel is calculated in accordance with s. 652. This figure is then multiplied by an amount of dollars calculated by converting gold francs into S.D.R.'s and then S.D.R.'s into Canadian dollars. See Canada Shipping Act Gold Franc Conversion Regulations SOR/78-73.

89. Canada Shipping Act, supra n. 3, s. 649(2).

90. Recently Courts have leaned against allowing limitation. It is described as a heavy onus and in order to succeed it must be established that there was total absence of fault or privity. See Stein v. The Kathy $K$ (1976) 62 D.L.R. (3d) 1 (S.C.C.). For a review of some situations where limitation was argued, see Temperley, supra, n. 40 at 174-5.

91. "The Lady Gwendolen" [1965] 1 Lloyd's Rep. 335 (C.A.).

92. Supra n. 90 at 13.

93. N.V. Bureau Wijsmuller v. "Tojo Maru"[1971] 1 Lloyd's Rep. 341 (H.L.). In that case a diver from a salvage tug caused damage to the ship being saved. The House of Lords held that since he was in the water at the time he could not be said to be on board, although they did express sympathy for the salvage company.Quaere whether it would make any difference if the diver was connected to the ship by hose, or operating out of a small submarine?

94. Willmer L.J. in The Lady Gwendolen supra n. 91 at 346. 
This admonition is, at present, particularly appropriate to offshore operations. As stated in the March, 1981 issue of Offshore magazine: ${ }^{95}$

The huge increase in mobile rigs operating in late 1979 and all of 1980 lead to the surge in the accident rate, a number of drilling contractors have commented:

"We have no reservoir of trained people in any area of mobile rig activity so when the rig fleet expands as it did in 1980, we have to stretch key people thinner and thinner".

Certainly, failure to man the rig competently with knowledge of the lack of competence would make limitation difficult. ${ }^{96}$

Finally, it should be noted that the 1976 Limitation Convention, ${ }^{97}$ if adopted in Canada, will substantially change the limitation issue. In particular, the Convention does not apply to "floating platforms constructed for the purpose of exploring or exploiting the natural resources of the seabed or the subsoil thereof ${ }^{\prime} \cdot{ }^{98}$

\section{Statutory Civil Liability for Oil Pollution and Limitation}

"Ship" generated oil pollution in non-Arctic waters is covered by Part $\mathrm{XX}$ of the Canada Shipping Act. ${ }^{99}$ Civil liability is imposed with respect to the owners of ships that carry pollutants in bulk, whether as cargo or otherwise ${ }^{100}$ (more than 1000 tons). Limitation is a vailable; ${ }^{101}$ the limitation fund is approximately double that discussed earlier. ${ }^{102}$ It is available to the person having the rights of the owner of the ship as regards possession and use. ${ }^{103}$

In the event that Mobil utilizes semi-submerged tankers of one million barrels capacity as storage tankers at Hibernia, ${ }^{104}$ the provisions of Part $\mathrm{XX}$ should apply to civil liability arising out of a discharge.

What is the position of a rig-owner/operator for pollution liability arising from a blowout at Hibernia or other non-Arctic site? (The effect of oil pollution liability contracts between the government and oil company operators will not be considered here. They are unclear as to the rights of non-parties, particularly the attempts to rank claims contained in such contracts.)

One may approach this problem assuming that the proposed amendments to The Oil and Gas Production and Conservation Act relating to oil spills are in effect. ${ }^{105}$ Section 19(1) is ambiguous and may mean:

a. "spill" is that type of discharge which is not caused by a "ship" as that word is defined in the Canada Shipping Act; or

b. "spill" is a discharge other than a discharge, as that word is defined in the Canada Shipping Act, caused by a ship.

95. Supra at 51-2.

96. The Empire Jamaica [1956] 3 All E.R. 144 (H.L.).

97. International Convention on Limitation of Liability for Maritime Claims, signed in London, November 19, 1976.

98. Id Article 15.5(b). As noted by Summerskill, supra $\mathrm{n} .41$ at 37 , the question is now one of purpose.

99. Supra n. 3. See Appendix B infra for definition of pollutant. Is drilling mud a pollutant?

100. Maritime Pollution Claims Fund Regulations, C.R.C. 1978, c. 1444.

101. Supra n. 3, s. 735(4).

102. Id.

103. Id. s. 727(1).

104. As recently reported in 3:1 Eastern Offshore News, and in the Oil and Gas Journah April 13, 1981 at 86.

105. See Appendix $\mathrm{C}$ infra. 
It is submitted that alternative (a) is what is intended by the draftsmen. If that is the case, what happens if a blowout causing damage is attributable to a self-propelled semi-submersible (a ship)? It may be argued that the owner/operator is then able to seek the protection of the general limitation provisions of the Canada Shipping Act. Part XX may not be relevant if the rig did not carry a pollutant in bulk (it is open to question whether the aggregate of all the pollutants on board, lube oils, fuel, mud, etc., would make the rig a bulk carrier of pollutants). If limitation were successfully argued, using the tonnage figures from the earlier example, the result would be:

Damage to plaintiffs

Limitation tonnage

$\$ 20$ Million

Approximate amount recoverable 10,000

$\$ 1$ Million

If the argument that the blowout was attributable to a ship was unsuccessful the strict liability provisions of the amendments may apply and the operator's liability will surely be more than $\$ 1$ million. It will be at least the limit of liability set by regulation.

The possibility seems to exist for at least three regimes of statutory civil liability for oil pollution arising out of one operation, for example, Hibernia:

a. limitation for the storage tanker at the limits set by Part XX of the Canada Shipping Act;

b. limitation for a rig in appropriate circumstances at the general limits of the Canada Shipping Act (one-half of Part XX limits);

c. no limitation for a rig under the Canada Shipping Act.

It is hard to imagine why a spill caused by a tanker in the Hibernia field should attract different liability than a blowout from the same location. The fact of different regimes of liability for ship and non-ship spills is, of course, a reality in Arctic waters. ${ }^{106}$ But in that case there is a clear distinction, which seems to be lacking in non-Arctic waters.

\section{CONVEYANCING AND MORTGAGING}

The Canadian ship registration system illustrates a number of significant implications of "ship" status. ${ }^{107}$

A ship registered in Canada is conveyed by a marine bill of sale, in the form set by the Ships Registration Forms Regulations. ${ }^{108}$ Mortgages must also be in the form prescribed. It is not possible to register other security documents at a ship registry. In Nova Scotia it is impossible to register a valid chattel mortgage in the chattel registry against a ship registered pursuant to the Canada Shipping Act. ${ }^{109}$

Legal titie to Canadian ships, insofar as companies are concerned, must be vested in a body corporate incorporated federally, provincially or under the law of another part of the Commonwealth. That body corporate must have its principal place of business within the incorporating jurisdiction: ${ }^{110}$

106. Arctic Waters Pollution Prevention Act, R.S.C. 1970 (1st Supp.), c. 2 and Regulations.

107. Contained in Part I of the Canada Shipping Act, supre n. 3.

108. SOR/81-121.

109. A chattel in the Bills of Sale Act, R.S.N.S. 1967, c. 23, s.1(c), excludes a registered ship.

110. Supra, n. 3, Form 8 Declaration of Ownership, the Canada Shipping Act, supra n. 3 is not as detailed as the form on this point, but $\mathbf{s .} 83$ of the Act provides the authority for a prescribed form. 
where all the important business of the Company is, in fact, controlled and managed at meetings of Directors or Managers of the Company.

It is also necessary for the legal owner to state that no unqualified person is entitled, as owner, to any interest whether legal or beneficial in the ship."' Filing of a false declaration may render the ship subject to forfeiture. ${ }^{112}$

Ships built outside of Canada cannot be registered in Canada without permission of the Minister of Transport. ${ }^{113}$ In addition, persons contemplating transfer to Canadian flag should ascertain in advance whether any changes will be required to the vessel and her equipment to ensure compliance with Canadian requirements.

Where beneficial title is in an entity other than the registered owner, one should be aware that the beneficial owner is liable to pecuniary penalties imposed by any Federal act on the owners of ships. ${ }^{114}$

A change in legal but not beneficial ownership will not extinguish claims in rem against the vessel. ${ }^{115} \mathrm{~A}$ change in beneficial ownership will extinguish some claims in rem not already crystallized into proceedings in Federal Court. ${ }^{116}$ However, maritime liens, which in Canada are not registered and cannot be ascertained by any registry search, and some statutory rights in rem, are not so extinguished. It is therefore important to secure an indemnity agreement from a vendor with respect to these matters. The statutory form of bill. of sale is not sufficient. If you are concerned that the vendor's only asset is the ship, guarantees from the principals should be provided.

An item of particular importance with rigs is spare parts and equipment. Some standard form ship agreements of sale refer to the ship and "everything belonging to her whether on board or ashore". ${ }^{117}$ If you are buying from a vendor with a number of rigs, the possibility exists that he may have a pool of spare parts on shore not appropriated to any particular rig. The question of spares onshore should be canvassed both in the agreement and by reference in the marine bill of sale. ${ }^{118}$ You should also ensure, quite apart from the law governing the sale of the ship, that you have title to the spares in accordance with the law of the place where the spares are situate.

\section{CUSTOMS, IMMIGRATION AND COASTING}

Oil rigs are not presently treated as ships for the purposes of customs. Neither are supply vessels engaged in the offshore oil industry. Both are

111. Id. See also s. 14(e) of the Canada Shipping Act, supra n. 3.

112. Section 85(2) of the Act, id. As to companies the principal criterion of, for example, a company incorporated in Canada is its "principal place of business". In The Polzeath [1916]P. 241 (C.A.) a British company controlled from Hamburg by the Chairman and majority shareholder had its principal place of business out of her Majesty's Dominions. The ship was forfeited to the Crown.

113. Id. s. 22.

114. Id. s. 75.

115. Federal Court Act, supra n. 6, s. 43(3).

116. Id.

117. See for example, Norwegian sale forms.

118. See Coltman v. Chamberlain (1890) 25 L.R. 328 (Q.B.D.); Hutchison v. Hawker Siddeley Canada Ltd. (1973) 32 D.L.R. (3d) 759; A rmstrong and Others v. M'Gregor \& Co. (1875) 12 Sc.L.R. 243. It is arguable that equipment on shore may not pass with the bill of sale as an appurtenance. This is even more so if the equipment is not designated for a particular rig. 
[VOL. XX, NO.1

considered to fall under that part of the Customs tariff which deals with oil drilling equipment and are considered as ancillary to that business. ${ }^{119}$ This status confers a lower duty than if they were treated as vessels. Customs exercises jurisdiction to the twelve mile limit. ${ }^{120}$ The Hibernia operation is not at present considered by Customs officials to be under their jurisdiction except for foreign flag supply vessels which operate out of St. John's, Newfoundland.

Rigs operating within twelve miles are treated as being within Canada for immigration purposes. ${ }^{121}$ The exemption from having employment authorizations accorded to foreign ships does not apply to rigs. ${ }^{122}$

The provisions of Part XV of the Canada Shipping Act do not apply to vessels supplying rigs off Newfoundland. ${ }^{123}$ These rigs are not treated as "ports in Canada" so that the provisions dealing with the coasting trade are not applicable. It is useful to note, however, that the Coasting Trade Exemption Regulations 1981-82 ${ }^{124}$ do make reference in the Schedule to supply vessels. Each situation must be judged on its own merit.

\section{CONCLUSION}

The relationship between Admiralty law, shipping legislation and oil rigs will take time to work itself out. Legislation must be drafted to specifically address the issues. ${ }^{125}$ Domestic shipping regulations, particularly in the areas of safety and manning, must deal with rigs, both when in motion and stationary. Many of the matters discussed in this paper can be dealt with by amendment to the appropriate statutes. Is it better to have Parliament decide a rig is or is not a ship, or to leave the question to a judge forced to a conclusion by counsel's argument that a rig is entitled to limitation of liability because it is a ship?

\section{APPENDIX A}

FEDERAL COURT ACT, s. 22

22. (2) Maritime jurisdiction - Without limiting the generality of subsection (1), it is hereby declared for greater certainty that the Trial Division has jurisdiction with respect to any claim or question arising out of one or more of the following:

(a) any claim as to title, possession or ownership of a ship or any part interest therein or with respect to the proceeds of sale of a ship or any part interest therein;

(b) any question arising between co-owners of a ship as to possession, employment or earnings of a ship;

(c) any claim in respect of a mortgage or hypothecation of, or charge on a ship or any part interest therein or any charge in the nature

119. Item 49104-1, Customs Tariff. This is apparently policy of Customs and Excise based on their interpretation of the general preamble to the oil drilling section of the tariff.

120. Customs Act, R.S.C. 1970, c. C-40, as am., s. 2(1).

121. The Rowan rig off Sable Island for $\mathbf{1 9 8 0 - 8 1}$ is so treated.

122. Immigration Regulations, 1978 C.R.C. 1978, c. 940. The exemption in s. 19(1)(e) only applies in respect of foreign vessels "engaged predominantly in the international transpor. tation of goods or passengers".

123. Supra n. 3.

124. SOR/81-287.

125. A Draft International Convention on Off-Shore Mobile Craft was adopted by the Comite Maritime Internationale in 1977. Most of the traditional admiralty matters are canvassed. The text is reproduced in Appendix $D$, infra 
of bottomry or respondentia for which a ship or part interest therein or cargo was made security;

(d) any claim for damage or for loss of life or personal injury caused by a ship either in collision or otherwise;

(e) any claim for damage sustained by, or for loss of, a ship including, without restricting the generality of the foregoing, damage to or loss of the cargo or equipment of or any property in or on or being loaded on or off a ship;

(f) any claim arising out of an agreement relating to the carriage of goods on a ship under a through bill of lading or in respect of which a through bill of lading is intended to be issued, for loss or damage to goods occurring at any time or place during transit;

(g) any claim for loss of life or personal injury occurring in connection with the operation of a ship including, without restricting the generality of the foregoing, any claim for loss of life or personal injury sustained in consequence of any defect in a ship or in her apparel or equipment, or of the wrongful act, neglect or default of the owners, charterers or persons in possession or control of a ship or of the master or crew thereof or of any other person for whose wrongful acts, neglects or defaults the owners, charterers or persons in possession or control of the ship are responsible, being an act, neglect or default in the management of the ship, in the loading, carriage or discharge of goods on, in or from the ship or in the embarkation, carriage or disembarkation of persons on, in or from the ship;

(h) any claim for loss of or damage to goods carried in or on a ship including, without restricting the generality of the foregoing, loss of or damage to passengers' baggage or personal effects;

(i) any claim arising out of any agreement relating to the carriage of goods in or on a ship or to the use or hire of a ship whether by charter party or otherwise;

(j) any claim for salvage including, without restricting the generality of the foregoing, claims for salvage of life, cargo, equipment or other property of, from or by an aircraft to the same extent and in the same manner as if such aircraft were a ship;

(k) any claim for towage in respect of a ship or of an aircraft while such aircraft is waterborne;

(l) any claim for pilotage in respect of a ship or of an aircraft while such aircraft is waterborne;

(m) any claim in respect of goods, materials or services whereever supplied to a ship for her operation or maintenance including, without restricting the generality of the foregoing, claims in respect of stevedoring and lighterage;

(n) any claim arising out of a contract relating to the construction, repair or equipping of a ship;

(o) any claim by a master, officer or member of the crew of a ship for wages, money, property or other remuneration or benefits arising out of his employment;

(p) any claim by a master, charterer or agent of a ship or shipowner in respect of disbursements or by a shipper in respect of advances, made on account of a ship;

(q) any claim in respect of general average contribution; 
(r) any claim arising out of or in connection with a contract of marine insurance; and

(s) any claim for dock charges, harbour dues or canal tolls including, without restricting the generality of the foregoing, charges for the use of facilities supplied in connection therewith.

43. (1) Subject to subsection (4) of this section, the jurisdiction conferred on the Court by section 22 may in all cases be exercised in personam.

(2) Jurisdiction in rem-Subject to subsection (3), the jurisdiction conferred on the Court by section 22 may be exercised in rem against the ship, aircraft or other property that is the subject of the action, or against any proceeds of sale thereof that have been paid into court.

(3) Exception-Notwithstanding subsection (2), the jurisdiction conferred on the Court by section 22 shall not be exercised in rem with respect to a claim mentioned in paragraph $22(2)(\mathrm{e}),(\mathrm{f}),(\mathrm{g}),(\mathrm{h}),(\mathrm{i})$, $(k),(m),(n),(p)$ or $(r)$ unless, at the time of the commencement of the action, the ship, aircraft or other property that is the subject of the action is beneficially owned by the person who was the beneficial owner at the time when the cause of action arose.

(4) Where action in personam may be commenced-No action in personam may be commenced in Canada for a collision between ships unless

(a) the defendant is a person who has a residence or place of business in Canada;

(b) the cause of action arose within the territorial, internal or other waters of Canada; or

(c) the parties have agreed that the Court is to have jurisdiction.

(5) Exception - Subsection (4) does not apply to a counterclaim or an action for a collision, in respect of which some other action has already been commenced in the Court.

(6) Where suit pending outside Canada - Where an action for a collision between ships has been commenced outside Canada, an action shall not be commenced in Canada by the same person against the same defendant on the same facts unless the action in the other jurisdiction has been discontinued.

(7) Ship owned by sovereign power - No action in rem may be commenced in Canada against

(a) any warship, coast guard ship or police vessel;

(b) any ship owned or operated by Canada or a province, or any cargo laden thereon, where such ship is engaged on government service; or

(c) any ship owned or operated by a sovereign power other than Canada, or any cargo laden thereon, with respect to any claim where, at the time the claim arose or the action is commenced, such ship was being used exclusively for non-commercial governmental purposes.

(8) Action for collision defined-In this Act, an action for collision includes an action for damage caused by one or more ships to another ship or ships or to property or persons on board another ship or ships as a result of carrying out or omitting to carry out a manoeuvre, or as a 
result of non-compliance with law, even though there has been no actual collision.

\section{APPENDIX B}

CANADA SHIPPING ACT, s. 727(1)

"oil" means oil of any kind or in any form and, without limiting the generality of the foregoing, includes petroleum, fuel oil, sludge, oil refuse and oil mixed with wastes but does not include dredged spoil;

"owner", in relation to a ship, means the person having for the time being, either by law or by contract, the rights of the owner of the ship as regards the possession and use thereof;

"pollutant" means

(a) any substance that, if added to any waters, would degrade or alter or form part of a process of degradation or alteration of the quality of those waters to an extent that is detrimental to their use by man or by any animal, fish or plant that is useful to man, and

(b) any water that contains a substance in such a quantity or concentration, or that has been so treated, processed or changed, by heat or other means, from a natural state that it would, if added to any waters, degrade or alter or form part of a process of degradation or alteration of the quality of those waters to an extent that is detrimental to their use by man or by any animal, fish or plant that is useful to man,

and without limiting the generality of the foregoing includes oil and any substance or any substance that is part of a class of substances that is prescribed by the Governor in Council, for the purposes of this Part, to be a pollutant;

"pollution prevention officer" means a person designated as a pollution prevention officer pursuant to section 731 .

\section{APPENDIX C}

\section{PROPOSED AMENDMENTS TO OIL AND GAS PRODUCTION} AND CONSERVATION ACT.

\section{"Oil and Gas Spills}

19. (1) In this section and sections 19.1 to 19.4, "spill" means a discharge, emission or escape of oil or gas other than one that is authorized pursuant to subsection (2) or any other Act of Parliament or that constitutes a discharge of a pollutant caused by or otherwise attributable to a ship within the meaning of the Canada Shipping Act.

(2) The Governor in Council may make regulations authorizing the discharge, emission or escape of oil or gas of such types, in such quantities, at such locations, under such conditions and by such persons as are specified in the regulations, but Her Majesty in right of Canada has no liability whatever to any person arising out of such authorization.

19.1 (1) No person shall cause or permit a spill on or from any area to which this Act applies.

(2) Where a spill occurs in any area to which this Act applies, any person who at the time of the spill is carrying on any work or activity related to the exploration for or development or production of oil or gas in the area of the spill shall, in the manner prescribed by the regulations, report the spill to the Chief Conservation Officer. 
(3) Every person required to report a spill under subsection (2) shall, as soon as possible, take all reasonable measures consistent with safety and the prevention of pollution to prevent any further spill, to repair or remedy any condition resulting from the spill and to reduce or mitigate any danger to life, health, property or the environment that results or may reasonably be expected to result from the spill.

(4) Where the Chief Conservation Officer is satisfied on reasonable and probable grounds that

(a) a spill has occurred in any area to which this Act applies and immediate action is necessary in order to effect any reasonable measures referred to in subsection (3), and

(b) such action is not being taken or will not be taken under subsection (3),

he may take such action or direct that it be taken by such persons as may be necessary.

(5) For the purposes of subsection (4), the Chief Conservation Officer may authorize and direct such persons as may be necessary to enter on the lands, premises or place where the spill has occurred and take over the management and control of any work or activity thereat.

(6) A person authorized and directed to take over the management and control of any work or activity under subsection (5) shall manage and control that work or activity and take all reasonable measures in relation to the spill that are referred to in subsection (3).

(7) Any costs incurred under subsection (6) shall be borne by the person who obtained an authorization under paragraph 3.2(1)(b) in respect of the work or activity from which the spill emanated and until paid constitute a debt recoverable by action in any court of competent jurisdiction as a debt due to Her Majesty in right of Canada.

(8) Section 16 applies, with such modifications as the circumstances require, to any action or measure taken or authorized or directed to be taken under subsections (4) to (6) as if it were taken or authorized or directed to be taken by order under subsection 14(1) and as if such order were not subject to an investigation.

(9) No person required, directed or authorized to act under this section is personally liable either civilly or criminally in respect of any act or omission in the course of complying with this section unless it is shown that he did not act reasonably in the circumstances.

19.2 (1) Where a spill occurs in any area to which this Act applies,

(a) the person who obtained an authorization under paragraph 3.2(1)(b) in respect of the work or activity from which the spill emanated is liable, without proof of fault or negligence, up to any applicable limit of liability, for

(i) all actual loss or damage incurred by any person as a result of the spill, and

(ii) the costs and expenses reasonably incurred by Her Majesty in right of Canada or any other person in taking any action or measure in relation to the spill under subsections 19.1(4) to (6); and

(b) all other persons to whose fault or negligence the spill is attributable or who are by law responsible for others io whose fault or negligence the spill is attributable are jointly and severally liable, to the extent determined according to the degree of the fault or negligence proved 
against them, for all actual loss or damage incurred by any person as a result of the spill.

(2) All claims under this section may be sued for and recovered in any court of competent jurisdiction in Canada and shall rank firstly in favour of persons incurring actual loss or damage, without preference, and secondly to meet any costs and expenses incurred by Her Majesty in right of Canada.

(3) Nothing in this section suspends or limits

(a) any legal liability or remedy for an act or omission by reason only that the act or omission is an offence under this Act or gives rise to liability under this section;

(b) any recourse, indemnity or relief available at law to a person who is liable under this section against any other person; or

(c) the operation of any applicable law or rule of law that is not inconsistent with this section.

(4) No proceedings in respect of a claim under this section may be instituted after two years from the day when the spill in question occurred or became evident.

19.3 The Minister shall require a person who obtained an authorization under paragraph $3.2(1)(b)$ in respect of any work or activity in any area to which this Act applies to provide for financial responsibility in respect of claims under section 19.2 in the form of a letter of credit, a guarantee or indemnity bond or in any other form satisfactory to the Minister, in an amount satisfactory to the Minister and payable on such terms and conditions and for the benefit of such persons or classes of persons as the Minister approves.

\section{Inquiries}

19.4 (1) Where a spill or an accident or incident related to any activity to which this Act applies occurs in any area to which this Act applies and results in death or injury or danger to public safety or the environment, the Minister may direct an inquiry to be made and may authorize any person or persons he deems qualified to conduct the inquiry.

(2) For the purposes of an inquiry under subsection (1), a person authorized by the Minister under that subsection has and may exercise all the powers of a person appointed as a commissioner under Part I of the Inquiries Act.

(3) The person or persons authorized to conduct an inquiry under subsection (1) shall ensure that, as far as practicable, the procedures and practices for the inquiry are compatible with investigation procedures and practices followed by any appropriate provincial authorities, and for such purposes may consult with any such authorities concerning compatible procedures and practices.

(4) As soon as possible after the conclusion of an inquiry under subsection (1), the person or persons authorized to conduct the inquiry shall submit a report to the Minister, together with the evidence and other material that was before the inquiry.

(5) A report made pursuant to subsection (4) shall be published by the Minister within thirty days after he has received it.

(6) The Minister may supply copies of a report published pursuant to subsection (5) in such manner and on such terms as he considers proper." 


\section{APPENDIX D \\ DRAFT INTERNATIONAL CONVENTION ON OFF-SHORE MOBILE CRAFT \\ Article 1 \\ DEFINITION}

In this Convention "craft" shall mean any marine structure of whatever nature not permanently fixed into the sea-bed which

a) is capable of moving or being moved whilst floating in or on water, whether or not attached to the sea-bed during operations, and

b) is used or intended for use in the exploration, exploitation, processing, transport or storage of the mineral resources of the sea-bed or its subsoil or in ancillary activities.

\section{Article 2 \\ COLLISIONS}

\section{A State Party which is also a party to}

- the International Convention for the unification of certain rules of law with respect to collision between vessels and Protocol of signature dated September 23, 1910, or to

- the International Convention for the unification of certain rules relating to jurisdiction in matters of collision dated May 10,1952, or to

- the International Convention for the unification of certain rules relating to penal jurisdiction in matters of collision or other incidents of navigation dated May 10, 1952 ,

shall apply the rules of such convention or conventions to craft to which they would not otherwise apply.

\section{Article 3}

SALVAGE

A State Party which is also a party to

- the Convention for the unification of certain rules of law relating to assistance and salvage at sea and Protocol of signature dated September 23,1910 , or to

- the said Convention with Protocol dated May 27, 1967, shall apply the rules of the said convention or conventions with Protocol to craft to which they would not otherwise apply.

\section{Article 4}

\section{ARREST}

A State Party which is also a party to the International Convention for the unification of certain rules relating to the arrest of sea-going ships, dated May 10,1952, shall apply the rules of that convention to craft to which they would not otherwise apply.

\section{Article 5}

\section{LIMITATION OF LIABILITY}

A State Party which is also a party to

- the International Convention for the unification of certain rules relating to the limitation of the liability of owners of sea-going vessels and Protocol of signature dated August 25, 1924, or to

- the International Convention relating to the limitation of the liability of 
owners of sea-going ships and Protocol of signature dated October 10, 1957 , or to

- the Convention on limitation of liability for maritime claims dated November 19, 1976,

shall, subject to Article 9 below, apply the rules of any such convention to craft to which they would not otherwise apply. In the case of the 1976 Convention, a State Party shall do so notwithstanding the provisions of Article 15, paragraph 5, of that convention.

\section{Article 6 \\ RIGHTS IN CRAFT}

A State Party which is also a party to

- the International Convention for the unification of certain rules relating to maritime liens and mortgages and Protocol of signature dated April 10, 1926, or to

- the International Convention for the unification of certain rules relating to maritime liens and mortgages dated May 27, 1967, or to

- the International Convention relating to registration of rights in respect of vessels under construction dated May 27, 1967,

shall, subject to Article 10 below, apply the rules of such convention or conventions to craft to which they would not otherwise apply, provided that the State Party has established a system of registration of rights in relation to such craft.

Where such a system permits the registration of ownership of craft, a right so registered in one State Party-shall be recognized by the other State Parties.

For the purpose of this Article a structure's status as a craft as defined in Article 1 shall be determined in accordance with the law of the State where a title to or a mortgage on such structure is registered.

\section{Article 7}

\section{LIABILITY FOR OIL POLLUTION}

Subject to the succeeding paragraph of this Article, a State Party which is also a party to the International Convention on civil liability for oil pollution damage dated November 29,1969 , shall apply the rules of that convention to the escape or discharge of oil contained in craft, in so far as they would not otherwise apply.

A State Party shall apply such rules only in the absence of other applicable provisions on liability contained in other International Conventions to which it is a party.

\section{Article 8}

\section{APPLICATION OF NATIONAL RULES}

Subject to the provisions contained in Articles 9 and 10, a State Party, in so far as it is not a party to a convention referred to in Articles 2, 3, 4,5,6 or 7, shall apply to craft the rules which the State Party applies to vessels, in relation to the subject matters dealt with in any such convention.

Nevertheless, a State Party may, when enacting legislation with regard to vessels subsequent to this convention coming into force for that State, exclude craft which are not vessels from the application of such new legislation. 
Article 9

MINIMUM LIMITS OF LIABILITY FOR PLATFORMS

For the purpose of calculating the limit of liability under Articles 5 and 7 , craft which are platforms shall be deemed to be of not less than $x$ tons. The same shall apply to the limit of liability under national law pursuant to Article 8 above if and insofar as such a limit is based on tonnage.

\section{Article 10}

\section{MARITIME LIEN IN RESPECT OF POLLUTION}

No maritime lien shall attach to craft in respect of liability for pollution damage of whatever nature other than that imposed by Article 7 or similar rules applicable under Article 8.

Article 11

NATIONALITY

If, under any of the conventions applicable pursuant to Articles 2, 3, 4, 5,6 and 7 or the national rules pursuant to Article 8 , nationality is a relevant factor, a craft shall be deemed to have the nationality of the State in which it is registered for title or, if not so registered, the State of its owner.

Article 12

SAVINGS

Nothing in this Convention shall affect the rights or obligations of any person or company in the capacity of concessionaire, licensee or other holder of rights with respect to mineral resources. 